\title{
STRATEGI “PT. GITA FOOD” MEMENANGKAN PERSAINGAN
}

\author{
DEVITA PERMATASARI - 030670864 \\ UNIVERSITAS TERBUKA
}

\section{Profil Perusahaan}

PT Gita Food merupakan perusahaan yang sedang mengembangkan produk baru makanan pokok beras sehat, Lebih dikenal dengan nama GITA SNACK berpengalaman lebih dari 30 tahun sebagai distributor makanan ringan. Jaringan distribusi adalah Jawa, Bali dan Lombok. Beberapa tahun terakhir mengembangkan wilayah distribusi ke sebagian Sumatra yaitu di Lampung, Medan dan sekitarnya.

2. Jenis produk yang dijual dan harganya

Salah satu jenis produk yang dijualnya adalah Sego Jagung (beras jagung) dan Sego Singkong (beras jagung), harganya untuk kemasan 700gram kisaran Rp. 12.500 - Rp. 15.000

3. Bentuk Promo siapa yang dilakukan

Bentuk promo yang di lakukan oleh SPG door to door ke masyarakat, pasar, toko toko, apotek, dll. Beberapa waktu lalu di lakukan dengan promosi di beberapa media elektronik maupun cetak.

4. Siapa saja Konsumen yang membeli produknya

Konsumen yang membeli mayoritas orang dewasa, penderita diabet.

Analisis Anda dengan menjawab pertanyaan berikut ini :

a. Merujuk pada faktor-faktor segmentasi, menurut Anda karakteristik konsumen usaha tersebut termasuk factor segmentasi yang mana? Jelaskan Alasan Anda!

Konsumen usaha termasuk factor segmentasi, yang memilah memulai hidup sehat, karena dari segi manfaat produk yang di tawarkan lebih banyak serat, tanpa pewarna, tanpa pengawet, tanpa perasa serta bermanfaat melancarkan pencernaan.

b. Sebutkan strategi apa saja yang perlu dilakukan agar usaha tersebut berada pada posisi yang terbaik di pasar?

- Strategi penetrasi pasar, strategi pemasaran yang dilakukan perusahaan dalam melayani pasar yang ada, atau menjangkau pelanggan-pelanggan baru dengan karakteristik yang sama, dengan menggunakan bauran pemasaran yang ada.

- Strategi pengembangan produk, yaitu strategi pemasaran yang dilakukan perusahaan dalam melayani segmebn pelanggan yang ada dengan menawarkan lebih dari satu bauran pemasaran

- Strategi pengembangan pasar, yaitu strategi pemasaran yang ditujukan untuk melayani lebih dari satu segmen pelanggan dengan menggunakan satu bauran pemasaran. 


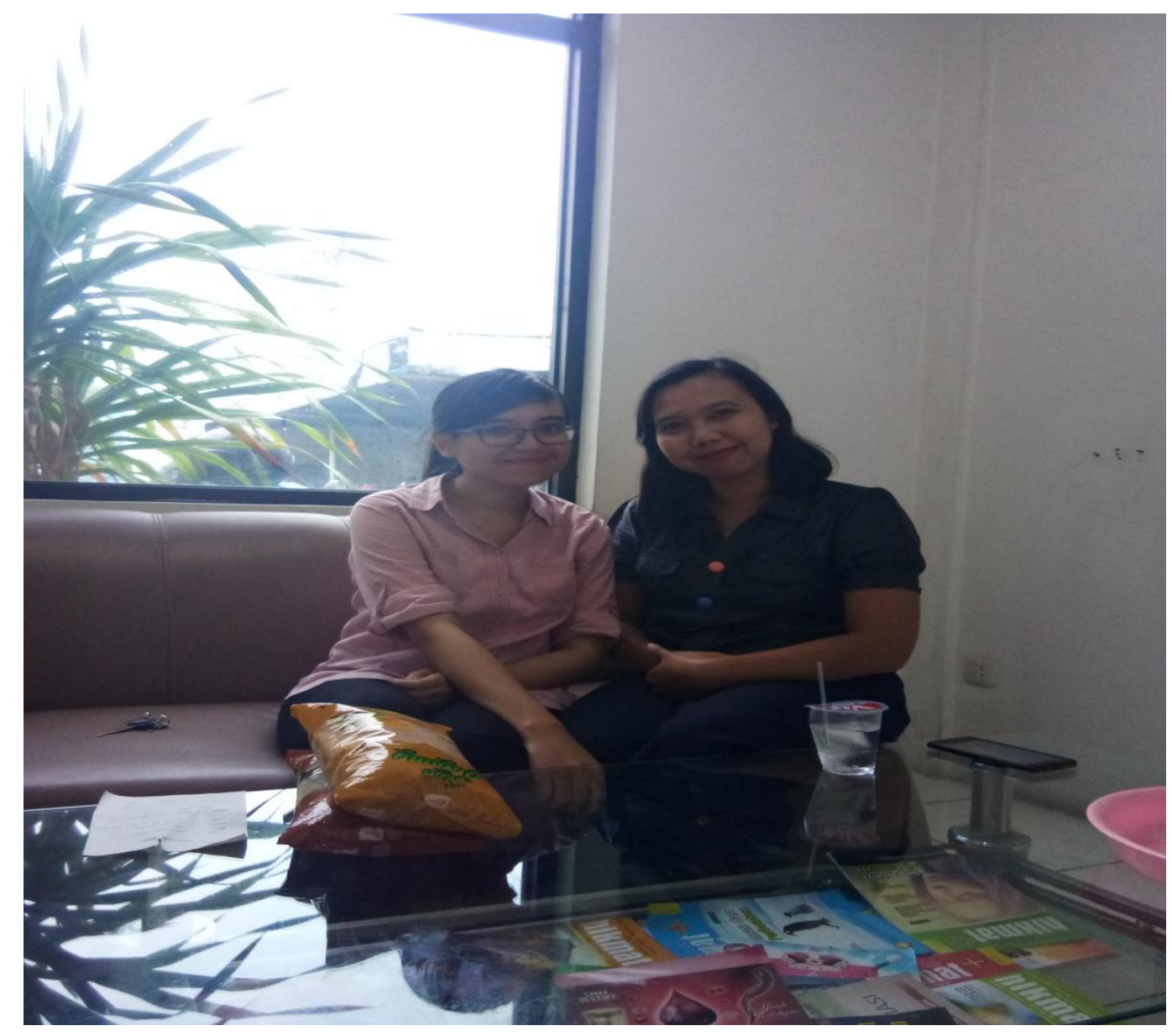

Foto dengan Ibu. Ari Astuti (Kabag Personalia PT. Gita Food)

Alamat : Jl. Indronoto Km. 0,7 Ngabeyan, Kartasura, Sukoharjo

\section{Referensi :}

[1] Mulyana, M., Hidayat, L. and Puspitasari, R., 2019. Mengukur Pengetahuan Investasi Para Mahasiswa Untuk Pengembangan Galeri Investasi Perguruan Tinggi. JAS-PT (Jurnal Analisis Sistem Pendidikan Tinggi Indonesia), 3(1), pp.31-52.

[2] Pauziah, P. and Mulyana, M., 2018. Formulation of The Green Marketing Development Strategy for the Body Shop Botani Square Bogor. In THE INTERNATIONAL CONFERENCE ON ACCOUNTING AND MANAGEMENT SCIENCE (p. 171).

[3] Setiawan, B., Puspitasari, R. and Manurung, T.M.S., 2016. The existence of Islamic banking in Indonesia from non-muslims perceptions. ASEAN Marketing Journal, pp.81-96.

[4] Djanegara, M.S., 2017. Pengaruh kualitas audit terhadap kualitas laporan keuangan pemerintah daerah. Jurnal Akuntansi, 21(3), pp.461-483.

[5] Rosita, S.I., 2014. Pengaruh Sistem Bagi Hasil Deposito Mudharabah Terhadap Minat Nasabah Berinvestasi Pada Bank Syariah. Jurnal Ilmiah Akuntansi Kesatuan, 2(1), pp.085-098. 
[6] Yalmaf, Y. and Nurjanah, Y., 2014. ANALISIS HUBUNGAN ANTARA LABA AKUNTANSI DAN ARUS KAS OPERASI DENGAN DIVIDEN KAS. Jurnal Ilmiah Akuntansi Kesatuan, 2(2).

[7] Pamungkas, B., 2008. Akuntabilitas Instansi Pemerintah, Survei Pada Pemerintah Dati II DI Yogyakarta.

[8] Pamungkas, B., 2018. Determinan penerapan basis akrual secara penuh pada pemerintah daerah. Jurnal Akuntansi, 22(1), pp.68-85.

[9] Purba, J.H.V. and Munawar, A., 2008. Kajian Dampak Pelatihan terhadap Kinerja Karyawan. Jurnal Ilmiah Ranggagading (JIR), 8(2), pp.95-102.

[10] Munawar, A., 2010. Analisis Nilai Tambah Dan Pemasaran Kayu Sengon Gergajian (Studi Kasus di Kecamatan Cigudeg Kabupaten Bogor).

[11] Purba, J.H., 2001. Model Ekonometrika Kelapa Sawit Indonesia, Analisis Simulasi Kebijakan Internal dan Eksternal. Jurnal Kopertis Wilayah, 4, p.12. 